\title{
DETERMINATION OF HEAD LOAD AND POWER REQUIREMENT FOR DEVELOPMENT OF BIN TYPE PADDY DRYER
}

\author{
SWAMY. R, SIVALA. K, SMITH. D. D, SADASIVARAO. K \& LAKSHIMIPATHY. R \\ College of Agricultural Engineering, Bapatla, Guntur, India
}

\begin{abstract}
Harvested paddy grain with high moisture content must be dried to about 12 percent (w. b) within 24 hours for safe storage and milling. The amount moisture evaporated from paddy was $86.64 \mathrm{~kg}^{\mathrm{batch}} \mathrm{bf}^{-1} \mathrm{o0} \mathrm{kg}_{\mathrm{g}} \mathrm{pddy}$ dried from moisture content of $25 \%(w . b)$ to $12 \%(w . b)$. The bulk density of paddy was determined $609 \mathrm{~kg}^{-\mathrm{m}^{-3}}$ at $25.0 \%$ (w. b) moisture content Heat transfer from the paddy was calculated $2.26 \mathrm{MJ} \mathrm{kg}^{-1}$ as bottom layer and top layer grain temperature $60^{\circ} \mathrm{C}$ and $30^{\circ} \mathrm{C}$ respectively. Total heat was calculated $250 \mathrm{MJ}$ for a period of 8 hours paddy drying. Height of the air column was calculated $247.0 \mathrm{~m}$ for pressure drop of $63.17 \mathrm{~cm}$ of water. The power requirement for blower calculated as $3.0 \mathrm{Hp}$ for $500 \mathrm{~kg}$ paddy bin drying. Based on the design calculation $500 \mathrm{~kg}$ capacity paddy dryer was developed.
\end{abstract}

KEYWORDS: Paddy Dryer, Heat Load \& Static Pressure Drop

Received: Jan 29, 2018; Accepted: Feb 19, 2018; Published: Mar 09 2018; Paper Id.: IJASRAPR201811

\section{INTRODUCTION}

Rice is the agricultural commodity with the third highest worldwide production of 741.5 million tonnes in the year 2014 after sugarcane and maize crop (FAOSTAT, 2017). India has the largest area under paddy and second largest producer of paddy accounting 22.40 percent of total world production (FAOSTAT, 2013). Andhra Pradesh is the third largest producer of paddy in India and production was 128.95 lakh tonnes during the year 2014-2015, with an average productivity of 3.15 tonnes per hectare from $34.40 \mathrm{~m}$ ha. Food grain production in India, 2016 was estimated at 273.38 million tonnes. Production of paddy has increased significantly by 4.74 million tonne $(4.54 \%)$ than the production of 104.41 million tonnes during 2015-16.

Harvested paddy grain with high moisture content must be dried to about 12 percent (w. b) within 24 hours for safe storage and milling. Approximately 9 percent of paddy was lost due to outdated drying methods, milling, unscientific method of storage, transport, and handling (Basavaraj et al., 2015). Drying paddy is one of the major problems in India. Before drying it is necessary to know amount heat requirement, air requirement, and power requirement for better drying. Hence, those calculations were presented in this paper.

\section{MATERIAL AND METHODS}

Freshly harvested, local paddy variety $R N R-2458$ was selected and procured from Agricultural Research Station, Rajendranagar Hyderabad to conduct the experiments. The paddy was passed through a cleaner and an aspirator to remove foreign matter, broken, chaff, and immature grains. 


\section{Moisture Content}

The moisture content of paddy samples was determined by drying $10 \mathrm{~g}$ samples in an oven at $105 \pm 1^{\circ} \mathrm{C}$ for 24 hours (Araullo et al., 1976). The samples were weighed in precision electronic balance having least count of $0.001 \mathrm{~g}$. The moisture content was calculated by the loss of moisture per unit weight of paddy.

$$
m . c=\frac{W_{m}}{\left(W_{m}+W_{d}\right)} \times 100
$$

Where

$$
\begin{array}{ll}
\text { m. c. (w. b.) } & =\text { Moisture content, } \% \\
\mathrm{~W}_{\mathrm{m}} & =\text { Weight of moisture content, } \mathrm{g} \\
\mathrm{W}_{\mathrm{d}} & =\text { Weight of bone- dry material, } \mathrm{g}
\end{array}
$$

\section{Bulk Density}

The bulk density was calculated as the ratio of paddy weight to the volume occupied (AOAC Standard method). Bulk density was measured with $50 \mathrm{ml}$ cylinder, which was filled with paddy up to $15 \mathrm{~cm}$ height. The excess paddy was removed and the weight recorded.

\section{RESULTS AND DISCUSSIONS}

Initial moisture content was recorded as $25.0 \%$ (w. b) and considered for the study of drying characteristics. Heat load required for design and development of $500 \mathrm{~kg}$ capacity paddy dryer was determined to help of physical properties of paddy and air properties. The bulk density of paddy was measured $609 \mathrm{~kg} . \mathrm{m}^{-3}$ at $25.0 \%$ (w. b) moisture content.The amount of moisture evaporated from paddy was $86.64 \mathrm{~kg}$. batch ${ }^{-1}$ of $500 \mathrm{~kg}$ paddy dried from moisture content from $25 \%$ (w. b) to $12 \%$ (w. b) and the total amount of heat required was $250 \mathrm{MJ}$ for a period of 8 hours paddy drying.

Table 1: Amount Moisture Evaporated from Paddy was Calculated

\begin{tabular}{|l|l|c|l|}
\hline a) & Initial moisture content (w. b. $)$ & $=$ & $25 \%$ \\
\hline b) & Final a moisture content $($ w. b. $)$ & $=$ & $12 \%$ \\
\hline c) & Capacity of batch type dryer & $=$ & $500 \mathrm{~kg}$ \\
\hline & $\begin{array}{l}\text { The amount of moisture to be } \\
\text { evaporated from grain }\end{array}$ & $=$ & $500(1-0.12)\left(\frac{25}{100-25}\right) \times 100-\frac{12}{100-12} \times 100$ \\
\hline & & $=$ & $440(0.333-0.136)$ \\
\hline & \multicolumn{2}{l}{} & $86.64 \mathrm{~kg} / \mathrm{batch}$ \\
\hline
\end{tabular}

Table 2: Total Amount of Heat Required for Paddy Calculated as Follows

\begin{tabular}{|l|l|l|l|}
\hline i) & Temperature of grain, bottom layer & $=60 \mathrm{C}$ \\
\hline & Top layer & $=30^{\circ} \mathrm{C}$ \\
\hline ii) & Specific heat of grain, (cp) & $=0.4 \mathrm{kcal} \mathrm{kg}^{-1}{ }^{\circ} \mathrm{C}^{-1}$ \\
\hline iii) & Latent heat of vapourization of water & $=540.4 \mathrm{kcal} \mathrm{kg}^{-1}$ \\
\hline & & $=2.26 \mathrm{MJ} \mathrm{kg}^{-1}$ \\
\hline iv) & Drying period & $=8 \mathrm{hours}^{\circ}$ & $440 \times 0.333 \times 1.0(60-30)$ \\
\hline & Sensible heat transfer & $=4400 \mathrm{kcal}$ \\
\hline & & $=18.43 \mathrm{MJ}$ \\
\hline & & $=440 \times 0.4(60-30)$ \\
\hline & Sensible heat of grain & $=5280 \mathrm{kcal}$ \\
\hline & & $=22.11 \mathrm{MJ}$ \\
\hline
\end{tabular}




\begin{tabular}{|c|c|c|c|}
\hline \multicolumn{4}{|c|}{ Table 2: Contd., } \\
\hline & $\begin{array}{l}\text { Latent heat of water vapour } \\
\text { evaporated }\end{array}$ & $=$ & $86.64 \times 540$ \\
\hline & & $=$ & $46785.6 \mathrm{kcal}$ \\
\hline & & $=$ & $195.92 \mathrm{MJ}$ \\
\hline \multirow[t]{5}{*}{ v) } & Total heat required & $=$ & $5280.0+4400.0+46785.6$ \\
\hline & & $=$ & $56,465.6$ \\
\hline & & $\simeq$ & $60000 \mathrm{kcal}$ \\
\hline & & $\simeq$ & $250 \mathrm{MJ}$ \\
\hline & \multicolumn{3}{|c|}{80 per -cent heat transfer efficiency } \\
\hline \multirow{4}{*}{ vi) } & Rate of heat reguired & $=$ & $60,000.0$ \\
\hline & & & $8 \times 0.8$ \\
\hline & & $=$ & 9375.0 \\
\hline & & $=$ & $40 \mathrm{MJ} \mathrm{h}^{-1}$ \\
\hline
\end{tabular}

Table 3: Amount Air Required for 500 Kg Paddy was Calculated with Consideration of Ambient Air Conditions

\begin{tabular}{|c|c|c|c|}
\hline \multicolumn{4}{|c|}{ By using Psychrometric chart air properties were obtained } \\
\hline i) & Ambient air temperature & $=$ & $30^{\circ} \mathrm{C}$ \\
\hline ii) & Relative humidity of air & $=$ & $70 \%$ \\
\hline iii) & Absolute humidity of ambient air $(\mathrm{H})$ & $=$ & $0.019 \mathrm{~kg} \mathrm{~kg}^{-1}$ \\
\hline \multirow[t]{5}{*}{ iv) } & Humid heat of ambient air, $\mathrm{S}$ & $=$ & $0.24+0.45 \mathrm{H}$ \\
\hline & & & $=0.24+0.45 \times 0.019$ \\
\hline & & & $=0.24855 \mathrm{kcal} \mathrm{kg}^{-1}{ }^{\circ} \mathrm{C}^{-1}$ \\
\hline & & & $=1.04 \times 10^{-3} \mathrm{MJ} \mathrm{kg}^{-1}{ }^{\circ} \mathrm{C}^{-1}$ \\
\hline & \multicolumn{3}{|l|}{ Let $\mathrm{G}$ be the rate of air supply in $\mathrm{kg} \mathrm{min}^{-1}$} \\
\hline \multirow[t]{16}{*}{ v) } & \multicolumn{3}{|l|}{ Heat supplied by the hot air in 8.0 hours. } \\
\hline & & $=$ & G. S. $\left(\mathrm{t}_{2}-\mathrm{t}_{1}\right) \mathrm{d}_{\mathrm{t}}$ \\
\hline & & $=$ & $0.24855 \times(45-20) \times 480 \mathrm{G}$ \\
\hline & & $=$ & $2982.6 \mathrm{G}$ \\
\hline & & $\underline{\underline{z}}$ & $3000 \mathrm{G}$ \\
\hline & where & & \\
\hline & $\mathrm{S}$ is the specific heat of air & & \\
\hline & $\mathrm{S}$ & $=$ & $0.24855 \mathrm{kcal} \mathrm{kg}^{-1}{ }^{\circ} \mathrm{C}^{-1}$ \\
\hline & & $=$ & $1.04 \times 10^{-3} \mathrm{MJ} \mathrm{kg}^{-1}{ }^{\circ} \mathrm{C}^{-1}$ \\
\hline & \multicolumn{3}{|c|}{$\mathrm{t}_{2}=$ Inlet temperature of air to grain $\left(45^{\circ} \mathrm{C}\right)$} \\
\hline & \multicolumn{3}{|c|}{$\mathrm{t}_{1}=$ Outlet temperature of air from grain $\left(20^{\circ} \mathrm{C}\right)$} \\
\hline & \multicolumn{3}{|c|}{$\mathrm{d}_{\mathrm{t}}=$ Time of drying $=8 \times 60$} \\
\hline & & $=$ & $480 \mathrm{~min}$. \\
\hline & $\therefore 3000 \mathrm{G}$ & $=$ & 60,000 \\
\hline & $\mathrm{G}$ & $=$ & $20 \mathrm{~kg} \mathrm{~min}^{-1}$ \\
\hline & from Psychrometric chart & & \\
\hline vi ) & Humid volume of the ambient air & $=$ & $0.884 \mathrm{~m}^{3} \mathrm{~kg}^{-1}$ \\
\hline \multirow[t]{12}{*}{ vii) } & Air required & $=$ & $20 \times 0.844$ \\
\hline & & $=$ & $17.68 \mathrm{~m}^{3} \mathrm{~min}^{-1}$ \\
\hline & & $=$ & $18.0 \mathrm{~m}^{3} \mathrm{~min}^{-1}$ \\
\hline & Cross sectional area of plenum chamber & $=$ & $\frac{\Pi}{4} \mathrm{~d}^{2}$ \\
\hline & & $=$ & $0.785 \mathrm{~m}^{2}$ \\
\hline & $\mathrm{d}=$ Diameter of plenum chamber & $=$ & $1.0 \mathrm{~m}$ \\
\hline & $\mathrm{h}=$ Height of the plenum chamber & $=$ & $0.064 \mathrm{~m}$ \\
\hline & Area of the perforations & $=$ & $50 \%$ \\
\hline & Area through which air passes & $=$ & $0.785 \times 0.5 \mathrm{~m}^{2}$ \\
\hline & & $=$ & $0.40 \mathrm{~m}^{2}$ \\
\hline & Air required $/ \mathrm{m}^{2}$ & $=$ & $18 / 0.40$ \\
\hline & & $=$ & $45.0 \mathrm{~m}^{3} \mathrm{~min}^{-1} \mathrm{~m}^{-2}$ \\
\hline
\end{tabular}


Table 4: Static Pressure Drop was Calculated for Paddy by the Following Equation ( Siebenmorgen Et. Al, 1987)

\begin{tabular}{|c|c|c|}
\hline $\mathrm{PD}$ & $=$ & $\mathrm{V}\left(\mathrm{b}_{1} \mathrm{~F}+\mathrm{b}_{2} \mathrm{M}+\mathrm{b}_{3} \mathrm{D}+\mathrm{b}_{4} \mathrm{~V}\right)$ \\
\hline where & & \\
\hline$b_{1}, b_{2}, b_{3}, b_{4}$ & $=$ & Regression coefficients \\
\hline \multicolumn{3}{|c|}{$\mathrm{b}_{1}=25.859, \mathrm{~b}_{2}=-90.056, \mathrm{~b}_{3}=5.587, \mathrm{~b}_{4}=9133.696$} \\
\hline PD & $=$ & Pressure drop, $\mathrm{Pa} \mathrm{m}^{-1}$ \\
\hline V & $=$ & Velocity, $0.75 \mathrm{~m} \mathrm{~s}^{-1}$ \\
\hline $\mathrm{F}$ & $=$ & Fines percentage, $10 \%$ \\
\hline $\mathrm{MC}$ & $=$ & Moisture content, $25 \%$ wet basis \\
\hline $\mathrm{BD}$ & $=$ & Bulk density, $609 \mathrm{~kg} \mathrm{~m}^{-3}$ \\
\hline \multicolumn{3}{|c|}{$=0.75(25.589 \times 10-90.056 \times 25+5.587 \times 609+9133.696 \times 0.75)$} \\
\hline & $=$ & $6194.95 \mathrm{~Pa} \mathrm{~m}^{-1}$ \\
\hline & $=$ & $63.17 \mathrm{~cm}$ of water \\
\hline Density of air & $=$ & $1.13 \mathrm{~kg} \mathrm{~m}^{-3}$ at NTP \\
\hline $\begin{array}{l}\text { Pressure drop } \\
\text { in terms of air } \\
\text { column }\end{array}$ & $=$ & $\frac{63.17}{100} \times \frac{1000}{1.13}$ \\
\hline & $=$ & $559.02 \mathrm{~m}$ \\
\hline
\end{tabular}

Table 5: Capacity of the Blower was Calculated

\begin{tabular}{|l|l|l|}
\hline Blower capacity & $=$ & $\frac{\text { height of air column }(\mathrm{m}) \times \text { Air flow rate }\left(\mathrm{kg} \mathrm{min}^{-1}\right)}{4500}$ \\
\hline & $=$ & $\frac{559.02 \times 20}{4500}$ \\
\hline & $=$ & $2.48 \mathrm{hp}$ \\
\hline To be on safe side & $\simeq$ & $3.0 \mathrm{hp}$ taken \\
\hline
\end{tabular}

\section{CONCLUSIONS}

Initial weight of $500 \mathrm{~kg}$ paddy samples was dried from moisture content $25 \%$ (w. b) to $12 \%$ (w. b). The amount moisture was evaporated from grain was $86.64 \mathrm{~kg}$ per batch. Heat transfer from the paddy was calculated $2.26 \mathrm{MJ}^{\mathrm{kg}}{ }^{-1}$ as the bottom layer and top layer grain temperature $60^{\circ} \mathrm{C}$ and $30^{\circ} \mathrm{C}$ respectively. Total heat was calculated $250 \mathrm{MJ}$ for a period of 8 hours paddy drying. Height of the air column was calculated $247.0 \mathrm{~m}$ for pressure drop of $63.17 \mathrm{~cm}$ of water. The power requirement for blower calculated as $3.0 \mathrm{hp}$ for $500 \mathrm{~kg}$ paddy bin drying.

\section{REFERENCES}

1. AOAC.1985. Official methods of analysis. Association of official analytical chemists, Washington DC.

2. Araullo, E. V., De Padua, D. B and Graham, M. 1976. Rice post harvest technology. International Development Research Centre. Ottawa, Canada. ASAE Standards. 1991.38 ed. St. Joseph. MI:ASAE.

3. Basvaraj, Ravireja, G., Srinivas, D., Ramappa, K. T and Sharanagouda, H. 2015. Compartive study of manual and mechanical rice puffing methods. International Journal of Agricultural Science and Research. 5(5): 209-216.

4. Chakraverty, A. 1995. Post harvest technology of Cereals, Pulses and Oilseeds. Oxford \& IBH Publishing Co. Pvt Ltd, New Delhi.

5. FAOSTAT, 2017. Food and Agriculture Organization of the United Nations.

6. Government of India. 2015. Annual report 2014-15, Department of Agriculture and cooperation, Ministry of Agriculture, Government of India. 
7. Siebenmorgen, T. J and Jindal, V. K. 1987. Airflow resistance of rough rice as affected by moisture content, fines concentration and bulk density. Transactions of the American Society of Agricultural Engineers. 30(4):1138-1143. 
